\title{
Ecosystems Services of the Tropical Rain Forest Environment: Lessons from the Cross River National Park, Nigeria
}

\author{
Benjamin A. Ambe, Usang N. Onnoghen \\ Department of Environmental Education, Faculty of Education, University of Calabar, Calabar, Nigeria \\ Email: benjamin.a.ambe@unical.edu.ng
}

How to cite this paper: Ambe, B. A., \& Onnoghen, U. N. (2019). Ecosystems Services of the Tropical Rain Forest Environment: Lessons from the Cross River $\mathrm{Na}$ tional Park, Nigeria. Journal of Geoscience and Environment Protection, 7, 1-10. https://doi.org/10.4236/gep.2019.711001

Received: August 21, 2019

Accepted: November 4, 2019

Published: November 7, 2019

Copyright ( 2019 by author(s) and Scientific Research Publishing Inc. This work is licensed under the Creative Commons Attribution International License (CC BY 4.0).

http://creativecommons.org/licenses/by/4.0/

\begin{abstract}
This paper essayed to examine ecosystem functions with a case study of the tropical rainforest environment of the Cross River National Park, Nigeria. The paper highlighted the important functions of the ecosystems to include Purification of air and water mitigation of floods and droughts, detoxification and decomposition of wastes, generation and renewal of soil and natural vegetation, pollination of crops and natural vegetation, control of the vast majority of potential agricultural pests, dispersal of seeds and translocation of nutrients, maintenance of biodiversity, protection from the sun's harmful ultraviolet rays among others. Problems associated with the rainforest ecosystems among which are logging, traditional methods of farming, poaching, excessive noise and encroachment were identified. The paper concluded by highlighting the way forward among others that, awareness creation should be stepped-up in Support Zone Communities; indigenes should be educated periodically on the benefits of the ecosystem services to not just humans but the forest resources and biodiversity themselves.
\end{abstract}

\section{Keywords}

Ecosystem, Services, Tropical Rainforests, Cross River National Park

\section{Introduction}

The tropical rainforest ecosystem plays an enormous role in the survival of man and other species of the immediate environment and other surrounding environments. These ecosystem services are unquantifiable and in most traditional settings taken for granted until such a time that such services are no longer available or limited. Ecosystems service is an ecological-economics consideration that emerged in the 1990s to forge attempts at attaching costs to hitherto envi- 
ronmental "freebees" to force man into giving a second thought at environmental conservation and sustainable development. Boyd and Benzhaf (2006) noted that "there are the contributions of nature to human welfare"

Pallister (2001) defines tropical rainforest as dense forest or jungle growing in hot, wet lowlands near the equator. These vegetation types have characteristic super-hot temperature (about $27^{\circ} \mathrm{C}$ ) all year round and get up to 80 inches $(2000$ $\mathrm{mm}$ ) of rain on the average per year. Tropical forest ranges from the dense equatorial rainforest regions are characterized by crowding of great numbers of plants and animal species. The vegetation zone corresponds to the areas Koppen classified as "Af" climatic types. This ecosystem according to Pallister (2001) contains the greatest vegetation cover on earth. Trees grow in layers, with a continuous canopy of tall trees below the very tall emergent. The author opines further that vines and creepers grow from tree to tree. Rainforests contain the greatest biodiversity on Earth, and it is in this diversity that the ecological services of the rainforest ecosystems are hinged upon.

It is in this light that Gretchen (1997) defined Ecological Services as the essential services we require for life provided for us by the natural world. These services include the interactions among organisms and their natural environments, including the cycling of water and basic nutrients that humans are able to use and capitalize on.

This research study is motivated by the desire for the researchers to examine whether the tropical rainforest of the Cross River National Park provides any ecological services to the people and the environment of the area. Worried also with the many challenges faced by the CRNP and the seemingly low visitor turnout, the researchers will love to add to the local and international body of knowledge and further bring to citizens and tourists attention the numerous benefits of the forests of the CRNP if any exist at all.

\section{Brief Description of the Cross River National Park}

Forests management in Nigeria is officially handled by the Nigeria National Park Service; there are 8 National Parks in Nigeria. The parks cover a total land area of approximately $20,156 \mathrm{~km}^{2}$, or about $3 \%$ of Nigeria's total land area. The Nigeria National Park Service (NNPS) is responsible for preserving, enhancing, protecting and managing vegetation and wild animals in the National Parks in the country. The NNPS is an agency under the Federal Ministry of the Environment, and is headed by a Conservator General; whereas, the Cross River National Park like each of the 8 National Parks is headed by a Conservator of Parks. The NNPS works closely with the Nigerian Tourism Development Corporation which assists in the marketing and communication to the entire world, the Ecotourism potentials of the various parks.

The Akamkpa and Oban Divisions of the Cross River National Park (CRNP) were established in 1988, it covers an area of $2800 \mathrm{~km}^{2}$, and its highest peak is almost $1000 \mathrm{~m}$ above sea level. The Okwangwo Division of the National Park was established in 1991 and administratively merged with the Akamkpa Divi- 
sion; it now covers about $4000 \mathrm{~km}^{2}$. The Cross River National park is the largest rainforest in Nigeria and it serves as home to many endangered species. It enjoys $2000 \mathrm{~mm}$ of rainfall annually; with a temperature range of $20^{\circ} \mathrm{C}-24^{\circ} \mathrm{C}$. The CRNP has 105 support zone communities surrounding the park. It is listed by the International Union of Conservation of Nation (IUCN) as a category $1 \mathrm{~V}$ on biodiversity hot list. Documents from the CRNP Head office in Akamkpa shows that, the park has 11,567 plant species, 77 of which are endemic to Nigeria; 75 mammals including forest elephants; 282 birds and 42 snake species, the park is also rich in epiphytes, ferns and orchids. Figure 1 is the map of Cross River National Park showing the study area. It should be noted as the map shows that the Cross River National Park is contiguous with both the Takarmanda Forest Reserve and Korop National Park in the Republic of Cameroon. This allows for seamless migration of species between the two parks especially the Low Land Gorilla.

\section{Literature Review}

The Economics of Ecosystems and Biodiversity (TEEB, 2010) defines ecosystem services as "the direct and indirect contributions of ecosystems to human well-being". They support directly or indirectly our survival and quality of life.

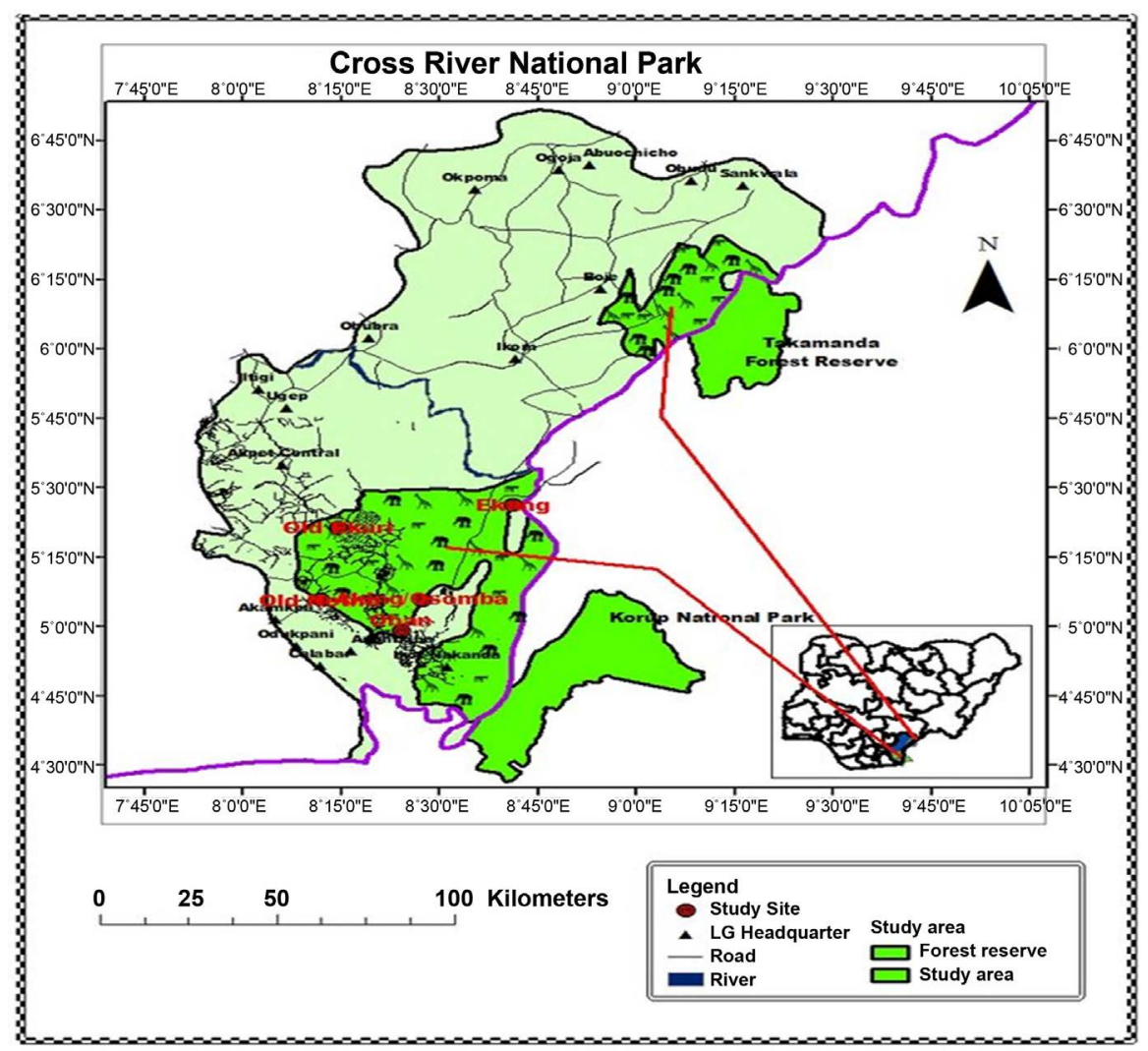

Figure 1. Map of Cross River National Park. Source: Jimoh, Adesoye, Adeyemi, \& Ikyaagba (2012). Forest Structure Analysis in the Oban Division of Cross River National Park, Nigeria. Journal of Agricultural Science and Technology, 2(B 2): 510-518. 
The author went on to note that ecosystem services are grouped into four broad categories; these are: provisioning services, such as the production of food and water; regulating services, such as the control of climate and disease; supporting services, such as nutrient cycles and oxygen production; and cultural services, such as spiritual and recreational benefits.

\subsection{Classification of Ecosystems Services}

The functions of ecosystems are described by some authors as "Ecological goods", and others as "Ecosystems Services", whatever nomenclature it bears, it boils down to the same meaning. The Economics of Ecosystems and Biodiversity (TEEB, 2010); Hansen, Frantzeskaki, McPhearson, Rall, Kabish, Kaczorowska, kain, Artmann and Paulet (2015) categorized ecosystem services broadly into four main types: these are:

1) Provisioning services: these are the products obtained from ecosystems such as food, fresh water, wood, fiber, genetic resources and medicines (Hansen, et al., 2015). Material outputs to the environment such as food supply, raw materials supply, water supply, medicinal resources, etc.

2) Regulating services: these services are defined as the benefits obtained from the regulation of ecosystem processes such as climate regulation, natural hazard regulation, water purification and waste management, pollination or pest control. Hansen, et al. (2015) described ecosystem processes that serve as regulators of ecological systems local climate regulation, air quality regulation, carbon sequestration and storage, noise reduction, run-off mitigation, moderation of extreme events, waste-water treatment, erosion prevention and maintenance of soil fertility, and pollination.

3) Habitat or supporting services: these services highlight the importance of ecosystems to provide habitat for migratory species and to maintain the viability of gene-pools. The provision of living spaces and maintenance of plant and animal diversity (serve as the foundation for all other services) habitat for species, maintenance of genetic diversity

4) Cultural services: these services include non-material benefits that people obtain from ecosystems such as spiritual enrichment, intellectual development, recreation and aesthetic values. Non-material benefits obtained from human contact with ecosystems recreation and mental and physical health, tourism, esthetic appreciation and inspiration, spiritual experience and sense of place, education and learning

In the same light of classifying Ecosystem services, Gretchen (1997) noted that these services include the interactions among organisms and their natural environments, including the cycling of water and basic nutrients that humans are able to use and capitalize on. These Ecological services as observed by Gretchen which are just a listing of the classification of other authors include:

- Purification of air and water;

- Mitigation of floods and droughts;

- Detoxification and decomposition of wastes; 
- Generation and renewal of soil and natural vegetation;

- Pollination of crops and natural vegetation;

- Control of the vast majority of potential agricultural pests;

- Dispersal of seeds and translocation of nutrients;

- Maintenance of biodiversity;

- Protection from the sun's harmful ultraviolet rays;

- Partial stabilization of climate;

- Moderation of temperature extremes and the force of winds and waves;

- Support of diverse human culture;

- Providing aesthetic beauty and intellectual stimulation that lift the human spirit.

Emphasizing on the functions of ecosystems, TEEB (2010) outlined the following as examples of ecosystem services:

1) Climate regulation: this is one of the most important ecosystem services both globally and on a local scale, ecosystems play a major role in climate regulation, terrestrial ecosystems represent a net carbon sink of some human generated emissions of carbon. Peat soils contain the largest single store of carbon. However, the climate regulating function of peat lands depends on land use and intensification (such as drainage and conversion to agriculture) and is likely to have profound impacts on the soil capacity to store carbon and on carbon emissions (great quantities of carbon are being emitted from drained peat lands).

2) Water purification: this service by ecosystems has a high importance for adjourning National Park communities. Both vegetation and soil organisms have profound impacts on water movements: vegetation is a major factor in controlling floods, water flows and quality; vegetation cover in upstream watersheds can affect quantity, quality and variability of water supply; soil micro-organisms are important in water purification; and soil invertebrates influence soil structure, decreasing surface runoff.

3) Pests and diseases: pests and diseases are regulated in ecosystems through the actions of predators and parasites as well as by the defense mechanisms of their prey. One example of these regulating services is provided by insectivorous birds in farms that use most of their land for agriculture.

4) Soil biodiversity: this service is a major factor in soil formation, which supports a range of provisioning services such as food, fiber and fuel provision and is fundamental to soil fertility.

5) Cultural services: these services provided by ecosystems are also very important to Nigerians. Although most people associate them mainly with nature conservation and tourism, well managed protected areas can provide vital ecosystem services, such as water purification and retention, erosion control and reduced flooding; in which case trees through their leaves reduce the amount of water that drops directly on the soil while the roots of trees retain water by not allowing free flow of water that would have caused flooding. They support food and health security by maintaining crop diversity and species, play an important role in climate change adaptation and contribute to mitigation through the sto- 
rage and sequestration of carbon.

In looking at the functions of the diverse ecosystems, Kaushik and Kausik, (2008) classified the functions of forest into two broad groups:

1) Environmental uses: under which the authors noted that forests are useful in regulation of water cycle, in the production of oxygen, absorption of pollutants, forests act as sinks for carbon dioxide, thereby reducing the severity of global warming, forests serve as habitat for wildlife and play a huge role in the conservation and nourishment of soils.

2) Commercial uses: in this classification, the author observed that forests provide timber, pulpwood, fruits, condiments, spices, beverages, fodder, rubber, gum, fibres, drugs and medicines as well as minerals.

According to TEEB (2010), a new classification of ecosystem services is under development at international level, which will be the Common International Classification of Ecosystem Services (CICES) to facilitate integration of ecosystem services in environmental accounting.

The Cross River National Park provides enormous ecological services for the immediate communities and other surrounding areas. Gretchen Daily (1997) observed that ecological goods are the products of the processes and interactions of natural systems. Plants they noted as for example capture energy from the sun, combined with water and nutrients from the soil and carbon dioxide from the atmosphere, are able to manufacture food for use by themselves and all other organisms. The food is considered a good. The decomposition of plant material according to Gretchen (1997) is an ecological service that results in soil production (an ecological good). This ecological good allows us to grow food agriculturally or with human assistance. The processes of seed dispersal and pollination of plants by birds and insects (an ecological service), produce plant (an ecological good). The nutrients we derive from plants we consume are ecological goods resulting from many ecological services. Ecological goods are not only valuable, but also essential to our survival. Our physical, cultural, social and economic lives are dependent upon these ecological goods that include: Clean air, fresh water, food (and the nutrients (vitamins and minerals) derived from plants and animals), Fiber, Timber, Other raw building materials, Genetic resources and Medicines.

\subsection{Impediments to the Ecosystem Services of the CRNP}

The problems associated with ecosystems services meeting their maximum utility value are not unconnected with the problems of forests preservation and conservation in general. Among these problems are:

1) Deforestation/logging: the Conservator of the CRNP Mrs. C. S. Olori decried that logging and deforestation are the major bane of the sustainability of the Park. She laments the encroachment into Park land by almost all the 105 host communities (Support Zone Communities) with exception of Ekuri community that has a community policy against deforestation. Deforestation is the 
cutting down of trees and the removal of vegetation or forest cover. Pallister (2001) noted that deforestation is a controversial issue. Some individuals and some governments wish to use the forest resources for their development whereas Environmentalists argue that deforestation has serious local and global consequences for the ecosystems functions; especially because, forests reduce runoffs and floods, use up carbon dioxide from the atmosphere and maintain the earth biodiversity.

NEST (1992) writing on deforestation in Nigeria; observed that, "forest clearance on a massive scale for agricultural development, urban growth, industrial expansion and general pressures from an increasing population have reduced the extent, diversity and stability of the Nigerian forest". This assertion is still true today even in the Cross River National Park. The general effect of logging and timber exploitation in Nigeria's forests according to NEST (1992) "is that the forest stability is disrupted and its ecosystem seriously disturbed. The disturbance in the words of Ambe, Eja, and Agbor (2015) is not only in its inability to regenerate through the natural process, but some species of flora and fauna are being endangered.

The CRNP host communities are basically agrarian; they depend on fuel wood hued from the reserve forests and the buffer zones of the reserves; this act in addition to picking of non-forest timber products by host communities threatens the ecosystems of the CRNP.

Ejidike and Ajayi (2013) writing on Threats to Ecological Goods and Services observed that Because of their importance, it is extremely important to reduce the threat of irreversible damage to our ecological systems caused by: Land-use change and irreversible conversion of landscapes and their ecological functions; disruption of bio-geochemical cycles, i.e. nitrogen, carbon and phosphorus cycles; disruption of the water cycle and ground water recharge; invasion by or introduction of exotic (non-native) organisms; toxins, pollutants and human wastes; changes in chemical composition of the atmosphere and ozone depletion; and climate change.

2) Poaching: The act of hunting for wildlife in otherwise protected areas by peasants to supplement their income/diets or for subsistence is regarded as poaching. In the CRNP area hunters still find their way into the protected areas way past the buffer zones to hunt/poach animals. These poachers even go as far as threatening the lives of Park Rangers. This practice is not mindful of the size, age or specie of the animal. They treat the endangered species the same way with other species that are not in danger of extinction. In the long run, the ecosystems are disrupted and the valuable functions/services they provide are lost forever.

3) Ownership rights: communities of the CRNP feel and insist that the land and the forest resources marked out as the CRNP belongs to the host communities and government has no right to impose boundaries on them and restrict them from enjoying their god-given treasures.

4) Bush burning and wildfires: bush burning is not perpetuated by only farmers; in some circumstances, bush fires are started by campers or tourists kno- 
wingly or unknowingly (Ambe, Eja, \& Agbor, 2015). Whereas natural factors like lightening can trigger-off wild bush fires that can destroy an entire forest system in hours.

5) Excessive Noise: the CRNP is so naturally endowed especially at the Akamkpa Division that, the entire Buffer zones communities of Nsan are covered with underground granitic rocks. These rocks are mined by almost ten companies who utilize grenades and dynamites to split open the huge mass of rocks underground on a daily basis. The excessive noise from these explosions scares away the animal population into the interior of the forests too far away from the buffer zone areas where tourists could have immediate benefits of sitting them without entering the forests.

From the forgoing, it has been observed that several authors and researchers have written on the value of the tropical rainforests, the various functions these rainforests play in the development and wellbeing of man and the various ways man is hindering the performance of these functions. The gap noticed upon review of literature lies in the fact that very little has been written to expose the numerous benefits of the Cross River National Park in terms of ecosystem services. This present study will bridge this gap and also contribute to existing body of knowledge in the area of ecosystems services of tropical rainforests.

Should the research study answer the question: what ecosystem functions are performed by the tropical rainforests environment of Cross River National Park? It shall have achieved its objective.

\section{Conclusion}

From the findings of this research, it can be concluded that the CRNP ecosystems play important functions in the environment, these functions include: $\mathrm{Pu}$ rification of air and water, mitigation of floods and droughts, detoxification and decomposition of wastes, generation and renewal of soil and natural vegetation, pollination of crops and natural vegetation, control of the vast majority of potential agricultural pests, dispersal of seeds and translocation of nutrients, maintenance of biodiversity, protection from the sun's harmful ultraviolet rays among others. It can also be concluded that the problems hindering the rainforest ecosystems of the CRNP from performing their natural role are logging, traditional methods of farming, poaching, exercise noise and encroachment.

\section{The Way Forward}

Owing to the enormous ecosystem functions/services of the Cross River National Park (CRNP), it is only wise to make frantic efforts to resolve the impediments to the ecosystem services of the CRNP. This cannot be done in isolation of the tropical rainforest itself but rather, the holistic preservation/conservation efforts being put together and managed by the authorities of the National Park Management should be upheld.

Government should provide needed social amenities like roads, pipe borne 
water, electricity, schools, hospitals and alternative sources of livelihood to the people of the buffer zones communities to reduce the pressure they mount on forest resources. Awareness creation should be stepped-up in Support Zone Communities; indigenes should be educated periodically on the benefits of the ecosystems services to not just humans but the forest resources and biodiversity themselves.

Indigenous people should be given scholarships to study environment based courses like Environmental Education, Botany, forestry, conservation studies so that when these graduates return home, they will help in spreading the conservation message to their country-men and women.

Patrol vehicles should be provided to help in quick intervention in cases of poachers and to show force within the support zone communities. Ejidike and Ajayi (2013) advocated a Biodiversity conservation strategy which will help to maintain healthy ecosystems; the author observed that, we have to strive to achieve a balance between society's ever-increasing need for goods and services and conservation of natural environments. Ecological zones influence local and global climate and man depends on suitable environment for his optimum performance. Building of infrastructures, staff capacities, making management plans, carrying out public enlightenments as well as immediate host community participation in park management are quite commendable conservation practices man is trying to implement for proper conservation of natural resources.

\section{Conflicts of Interest}

The authors declare no conflicts of interest regarding the publication of this paper.

\section{References}

Ambe, B. A., Eja, I. E., \& Agbor, C. E. (2015). Assessment of the Impacts and People's Perception of Bush Burning on the Grasslands and Montane Ecosystems of the Obanliku Hills/Plateau, Cross River State, Nigeria. Journal of Natural Sciences Research, 5,12-20.

Boyd, J., \& Banzhaf, S. (2006). What Are Ecosystem Services? Discussion Paper Resources for the Future DP 06-02, 26.

Ejidike, B. N., \& Ajayi, S. R. (2013). Trends in Wildlife Conservation Practices in Nigeria. International Journal of Biodiversity and Conservation, 5, 185-191. http://www.academicjournals.org/IJBC

Gretchen Daily (1997). Natures Services-Habitat as Infrastructure. A Review of Nature's Services: Societal Dependence on Natural Ecosystems. Island Press.

Hansen, R., Frantzeskaki, N., McPhearson, T., Rall, E., Kabish, N., Kaczorowska, A., Kain, J., Artmann, M., \& Paulet, S. (2015). The Uptake of the Ecosystem Services Concept in Planning Discourses of European and American Cities. Ecosystem Services. Elsevier, 12, 228-246. https://doi.org/10.1016/j.ecoser.2014.11.013

Jimoh, O. S., Adesoye, P., Adeyemi, A. A., \& Ikyaagba, E. T. (2012). Forest Structure Analysis in the Oban Division of Cross River National Park, Nigeria. Journal of Agricultural Science and Technology, 2, 510-518. 
Kaushik, A., \& Kausik, C. P. (2008). Environmental Studies (5th ed.). New Delhi: New Age International.

NEST (1992). The Challenges of Sustainable Development in Nigeria. Ibadan: NEST.

Pallister, J. (2001). GCSE Geography: Essential Word Dictionary. Deddington: Philip Allan.

The Economics of Ecosystems and Biodiversity (TEEB) (2010). The Economics of Ecosystems and Biodiversity and Economics Foundations. In P. Kumar, Ed., London \& Washington: Earthscan. 